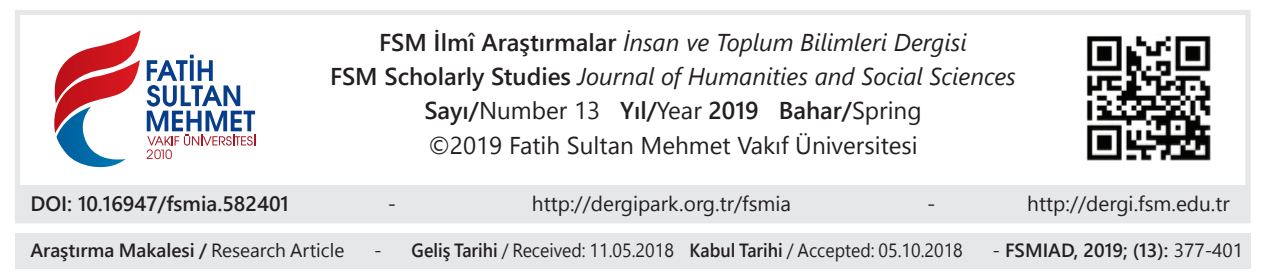

\title{
İslam ve Modernizm Karşılaşması: Geleneksel ve Modernist Söylemin Sorunları ve Bir Arayol Önerisi*
}

\author{
Ahmet Ayhan Koyuncu*
}

\section{$\ddot{O} z$}

İslamî düşüncenin önemli bir kısmı söylemsel düzlemde modern dünya ile ilgili olarak problemli bir tavra sahiptir. Bugün İslam dünyasında modern dünyaya bakışa ilişkin iki uç yaklaşım mevcuttur. Birinci yaklaşım modernliği bütünü ile reddeden ve "Altın Çağ'a" dönmeyi hedefleyen yaklaşımdır. İkinci yaklaşım ise modern dünyayı bütünüyle İslamîleştirmeyi hedefleyen yaklaşımdır. Bu anlamda birinci yaklaşıma devrimci tavır, ikinci yaklaşıma reformist tavır denilebilir. Ancak her iki yaklaşım da sorunlu yaklaşımlardır.

Geriye dönüş mümkün değildir. Bugün modern dünyanın içerisinde yaşıyoruz. Modern dünya, teknolojik, ekonomik, sosyal, siyasi vs. bazı yeni durumları beraberinde getirmiştir. Bu iki tavırla da Müslümanların sorunlarının çözülmesi mümkün değildir. Bu bağlamda yeni bir yaklaşıma ihtiyaç vardır. Bu bağlamda bu yeni yaklaşım, Hz. Peygamber'in içinde yaşadığı toplumla ilişki kurma biçimi olmalıdır.

Hz. Peygamber'in toplumuyla kurduğu ilişki üç boyutlu bir ilişkidir. Birinci boyutu devrimci boyut olarak da adlandırılabilir. Bu noktada Hz. Peygamber bazı uygulamaları kökten kaldırmıştır. Örneğin faiz, kaldırılmış ve yerine karz-1 hasen uygulaması önerilmiştir. İkinci boyutu islah boyutudur. Bu bağlamda uygulama tamamen kaldırılmamış, sadece 1slah edilmiştir. Örneğin çok evlilik yasaklanmamış, ancak sınırlanmıştır ve hukuki bir çerçeveye oturtulmuştur. Üçüncü boyut ise muhafazakâr boyut olarak adlandırılabilir. Bu yaklaşım, o toplumun iyi olan davranışlarını muhafaza etmektedir. Nitekim Hz. Peygamber, bir hadiste "cahiliyede iyi olan İslam'da da iyidir" buyurmaktadır. Örneğin haram aylar uygulaması, değiş̧tirilmeden muhafaza edilmiş ve haram aylarda savaş yapılmaması geleneği korunmuştur.

Bu çalışma, 6-8 Nisan 2016 tarihinde "1. Sosyal Bilimler ve Müslümanlar Kongresi: Hegemonya ve Karşı Hegemonya" sempozyumunda sunulmuş "Devrimcilik ve Reformizm Arasında: Müslümanların Modernlikle İlişkisine Dair Bir Yol Haritası Denemesi” başlıklı bildirinin gözden geçirilmiş ve düzenlenmiş halidir.

** Dr. Öğr. Üyesi, Afyon Kocatepe Üniversitesi Sosyoloji Bölümü, Afyonkarahisar/Türkiye, ahmetakoyuncu@hotmail.com, orcid.org/0000-0002-5401-7647. 
Sonuç olarak İslam, ne saf devrimci ne de saf reformist bir konuma sahiptir. İslam'ın genel uygulaması, olaylara göre şekillenmektedir. Bugün modern dünyanın bütünüyle reddedilmesi, olguya savaş açmaktır. Bütünüyle İslamîleştirilmesi ise İslamî ilkeleri realiteye kurban etmektir. Olguya savaş açmadan, ama ana ilkelerinden de taviz vermeden modern dünya ile kurulacak sağlıklı bir ilişki, Müslüman toplumlar için ivedi bir meseledir.

Anahtar Kelimeler: Devrimcilik, reformizm, İslam, modernlik, modern dünya.

\section{Encounter of Islam and Modernism: The Problems of Traditional and Modernist Discourse and an Offer of Midway}

\section{Abstract}

Today, an important part of Islamic thought has a problematic attitude regarding modern world on discursive level. Currently, there are two extreme approaches towards modern world in the Islamic world. One part of them rejects the modern world with its all characters completely and wants to return "Golden Age". Another part argues Islamization of the modern world with its all aspects. Both of these approaches, namely, revolutionism and reformism are having many problems.

Firstly, it is impossible to turn back. We live in modern world. But, modern world has come out with some new situations. These new situations are political, economic, technological, etc. Both of these approaches don't solve these problems. We need a new approach, a third way, towards modern world. In this context, the new approach must be our prophet's method.

While our prophet was spreading out the messages of Allah and he was calling to Islam, he applied three ways to change his society. First of all, he changed some practices entirely. For example, interest abolished and replaced karz-1 hasen, a special interest-free lending system. We can call this application revolutionist. Secondly, he revised some practices, for example polygamy didn't prohibit, but it limited and based on a legal framework. This applications can called reformist. And thirdly, he didn't change some practices and allowed to go on them. For example, forbidden moths are protected. In this context, Prophet Mohammad says "Good things in Jahiliyya are good in Islam as well." We can call conservatism for this application.

As a consequence, we can say that Islam is not merely revolutionist or merely reformist. Its position changes according to case. So, he offers a model for us to understand the world we live in. We, as Muslims, can understand modern world and figure out our problem with this triple approach.

Keywords: Revolutionism, reformism, Islam, modernity, modern world. 


\section{Giriş}

İslam dünyasının modernlikle tanışması 19.yy.da gerçekleşmiştir. Modernlikle tanışma, İslam dünyasının tarihinde yaşamış olduğu en büyük krizdir denebilir. Daha önce de çeşitli krizlerle karşılaşan İslam dünyası, bir şekilde bu krizleri aşmayı başarabilmişti. Ancak bu kriz bütün İslam dünyasında hemen hemen aynı dönemde oldukça derin bir şekilde yaşanması bakımından diğerlerinden ayrılmaktadır. Yaklaşık 200 yıldan bu yana da devam etmektedir. Bu süreçte Müslümanlar modern dünya ile olan yüzleşmede çeşitli tavırlar geliştirmeye çalışmışlardır. Bu yaklaşımlardan birincisi selefi tavırdır ve krizle yüzleşmektense kendi kabuğuna çekilerek korumacı bir tavırla sorunu aşmayı hedeflemektedir. İkinci ve baskın tavır modernlikle yüzleşerek, batılıların iddia ettiği gibi İslam dünyasının geri kalmasının nedeninin İslam olmadığını ve İslam’ın aslında son derece gelişmeye ve ilerlemeye açık bir din olduğunu ispatlama gayreti içinde olan bir yaklaşımdır. Bu yaklaşım modernliğin ve bilimin verilerini sorgulamaz ve İslam'ın modern düşünce yapısını içkin olduğunu ifade eder. Üçüncü yaklaşım ise kendisini modernist olarak ifade eden ve modernliğe teslim olmuş bir yaklaşımdır. İkinci yaklaşım tevil, yorum vs. ile aslında İslam ile modernliğin çelişmediğini ispat çabasındayken, üçüncü yaklaşım İslam ile modern dünyanın değerleri arasında bir çelişki olduğunda İslam'ın değerlerinin değiştirebilir olduğunu ileri sürmektedir. Örneğin İslam'1n ahkâm ayetlerinin tarihsel olduğunu ve o döneme göre ileri bir dönemi teşkil eden modern dönemde uygulanamayacağını savunur. Aslında bu düşünce modernliğin evrimci tarih tasavvurunun bir yansımasıdır. Dolayısıyla İslamî bir olgu ile modern bir olgu çeliştiğinde modern olguyu tercih ederek İslamî olgunun tarihsel olduğunu ve zamanın şartlarına göre değişebilir olduğunu, değişmesi gerektiğini ileri sürer.

$\mathrm{Bu}$ çalışma ise ikinci yaklaşımın içerisinde değerlendirilebilir. Ancak ikinci yaklaşımın modernliğe ilişkin bakışını problemli olarak ele almaktadır. Modernlikle de hesaplaşarak ve bu hesaplaşmada modern sonrası dönemdeki yaklaşımları da mutlak kabul etmeksizin faydalanarak, İslam dünyasının modern dünya ile ilişkisinin zeminine bir katkı sunmayı amaçlar. Bu çerçevede modernlikle hesaplaşan postmodern bakış açısından da faydalanır.

Çalışma sosyolojik bir zemin üzerinde kurulmaya çalışılmıştır. Sosyolojik zeminle kastedilen, olması gerekenden ziyade olanı merkeze almaktır. Bauman'ın da ifade ettiği gibi sosyolojinin bahsettiği her şey zaten hayatımızda olmuştur ${ }^{1}$. İslam ve modernlik meselesi üzerine yapılan tartışmanın toplumsal bir zemininin

1 Zygmunt Bauman, Sosyolojik Düşünmek, terc. A. Yılmaz, İstanbul, Ayrıntı Yayınları, 2016, s. 18 . 
olup olmadığı, toplumsal yaşama uygulanabilir olup olmadığı sosyolojik bakış açısının belirleyicisidir. Nihayetinde toplum, sosyolojinin hem öznesi hem de nesnesidir. $^{2}$

Bu bağlamda çalışma, dört bölümden oluşmaktadır. Çalışmanın birinci bölümünde İslam dünyasının modernlikle ilk tanışma sürecini kısaca ele alınmış, ikinci bölümde modernlikle tanışma sonrasında verilen tepkiler aktarılmıştır. Üçüncü bölümde, İslam dünyasının modernliğe yaklaşımında günümüz için azımsanmayacak etkileri olan iki uç yaklaşımı ele almıştır. Dördüncü bölüm ise Hz. Peygamber'in yaşadığ dönemde kendi toplumuyla kurduğu ilişki tahlil edilerek dönemin sosyolojik yapısı ve İslam'ın tarih tasavvuru çerçevesinde yeni bir model önerilmiştir. Sonuç kısmında ise genel bir değerlendirme yapılmıştır.

\section{I-) Modernlikle Tanışma}

İslam dünyasının modernlikle olan ilişkisi 19.yy.da başlamıştır ve bu ilişki günümüzde de bütün canlılığı ile devam etmektedir. Ancak İslam dünyasındaki İslamî hareketlerin ve Müslüman âlim ve aydınların modernlikle ilişkisi farklı perspektifler çerçevesinde gelişmiştir. İslam dünyasının Batı dünyası karşısında 18. ve 19. yüzyıllarda yaşamış olduğu yenilgiler, Batı dünyası üzerine düşünme ihtiyacını beraberinde getirmiş, İslam dünyası, uzun süre sağır kaldığı Batı karşısında hiç ummadığ 1 bir tarzda büyük çaplı bir yenilgiye uğramıştır. Daha önceleri de İslam dünyasında Müslüman devletlerin yenilgileri söz konusu olmuştur. Ancak bu yenilgiler, kısmi ve yerel kalmıştır. Bir başka coğrafyada güçlü olan başka bir İslam devleti varllğgnı ve gücünü korumuştur. Fakat 19. yüzyılda yaşanan yenilgiler, bütün bir İslam dünyasını etkisi altına almıştır. ${ }^{3}$ Üstelik sadece siyasi ve askeri alanlarda değil, bilimsel, düşünsel, kültürel, teknolojik, eğitimsel vs. her alanda bir gerileme söz konusu olmuştur. ${ }^{4}$

Başlangıçta askeri yenilgiler çerçevesinde başlayan Batı üzerine düşünme ihtiyacı öncelikle askeri alanlar üzerinde ve maddi boyutta yoğunlaşmıştır. ${ }^{5}$ Fakat daha sonra bu boyut, düşünce dünyasına ve bir bütün olarak yaşamın algılanış biçimine kadar kapsayıcı bir dönüşüme uğramıştır. Askeri alanda yaşanan yenilgiler, İslam ülkelerinde öncelikle modernleşmenin askeri bir karaktere sahip

2 Ergün Y1ldırım, Bilginin Sosyolojisi, Bursa, Ekin Yayınları, 2007, s.8.

3 Hulusi Şentürk, Türkiye'de İslami Oluşumlar ve Siyaset: İslamcılık, İstanbul, Çıra Yayınları, 2011, s. 64-65.

4 Mehmet Ali Büyükkara, Çağdaş İslami Akımlar, İstanbul, Klasik Yayınları, 2015, s.19.

5 Kenan Çağan, "Modern Bir İdeoloji Olarak İslamcılığın İcadı”, İdeoloji, ed. K. Çağan, Ankara, Hece Yayınları, 351; Muhammed Hüseyin, Modernizmin İslam Dünyasına Girişi, terc. S. Özel, İstanbul, İnsan Yayınları, s.15. 
olmasını beraberinde getirmiştir. Osmanlı Devletinin almış olduğu yenilgiler, askeri alanda modernleşme ihtiyacı düşüncesini doğurmuş, bu çerçevede askeri alanlara yönelik teknik ve ihtisas okulları tesis edilmiştir. Bu okullar içerisinde Mühendishane-i Bahri Hümayun (1773), Mühendishane-i Berri Hümayun (1796) Tibhane-i Ma'mure (1827), Cerrahane-i Ma'mure (1831) ve Mekteb-i Ulum-1 Harbiye (1834) gibi modern eğitim kurumları ilk oluşturulan okullar olarak sayılabilir. Ayrıca eski düzeni hatırlatacak şeylerin silinmesi bağlamında Mehterhane de ortadan kaldırılmış ve yerine Mızıka-yı Humayün mektebi adlı bir bando takımı kurulmuştur. Zamanla askeri alanların dışına da yönelinmiş ve geleneksel eğitim kurumları içerisinde yer alan Sıbyan mektebini bitiren çocuklar için Rüşdiye Mektepleri de kurulmuştur. 1838 yılında II. Mahmut tarafından açılan Rüşdiyeler ortaokul seviyesinde eğitim yapan kurumlardır ve bu kurumlarla birlikte sınıf sistemine geçilmiş, dersle umumi olarak verilmeye başlanmıştır. İki tür Rüşdiye oluşturulmuş, birincisine Mekteb-i Maarif-i Adliye (1838), ikincisine ise Mekteb-i Ulum-u Edebi (1839) adı verilmiştir. ${ }^{6}$ Böylece II. Mahmut döneminden itibaren İmparatorluk yapısı yeniden şekillendirilmeye çalışılmış ve özellikle Reşid Paşa döneminde güçlenen bir kurumsallaşma ortaya çıkmıştır. ${ }^{7}$

Modernliğin İslam dünyası ile tanışmasında etkili olan bir başka önemli unsur ise Avrupa'ya gönderilen öğrenciler vasıtasıyla gerçekleşmiştir. Avrupa'ya gönderilen öğrenciler, yeniliklerin kaynağından öğrenilmesi ve dil öğrenmeleri için gönderilmiştir. İlk kez III. Selim döneminde Avrupa’ya öğrenci gönderme başlamış, daha sonra yeniçeri ocağının kaldırılması sonrasında Babıali tarafında Avrupa'ya öğrenci gönderilmesine ağırlık verilmiştir. Tanzimat'ın ilanından sonra eşitlik ilkesi çerçevesinde gayr-1 Müslim öğrenciler de Avrupa'ya eğitim için gönderilmeye başlanmıştır. Gönderilen bu öğrencilerin mühendislik, tıp, harbiye, ziraat, madencilik vs. alanlarda eğitim alması ve dil öğrenmesi hedeflenmiştir. Kavalalı Mehmet Ali Paşa da 1809 yılından 1844 yılına kadar İtalya ve Fransa’ya eğitim almaları için öğrenciler göndermiştir. ${ }^{8}$.

Eğitim alanının dışında devlet idarecilerinin sefir olarak yurtdışına gönderilmesi de İslam dünyasının modernleşme sürecine etki eden üçüncü bir unsur olarak sayılabilir. Yurtdışına gönderilen elçiler, gördükleri yenilikleri ülkede uygulama hevesine kapılmışlardır. Böylece modernleşme süreci yeni bir boyuta geçmiş

6 Adil Şen, “Osmanlı'dan Günümüze Eğitimde Modernleşme Çabaları”, EKEV Akademi Dergisi, Cilt 17, Say1 57, Ekim 2013, s.481-483.

7 Şerif Mardin, Yeni Osmanlı Düşüncesinin Doğuşu, İstanbul, İletişim Yayınları, 2002, s.221.

8 Cafer Ulu, "1416 Sayılı "Ecnebi Memleketlere Gönderilecek Talebe Hakkında Kanun" ve Cumhuriyetin İlk Yıllarındaki Uygulamaları", Tarih Okulu Dergisi (TOD), Cilt 7, Sayı XVII, 2014, s. 496-497. 
ve devlet kurumlarına sıçramıştır. Batı memleketlerine elçilikle giden Osmanlı devlet adamları, orada uyanan yeni devlet anlayışının, hürriyet ve eşitlik fikrinin, insan haklarının vs. kaçınılmaz bir yol olduğunu düşünmüşlerdir. ${ }^{9}$ Genel olarak bu dönemdeki gelişmeler askeri odaklı modernleşmeden daha kapsamlı, politik odaklı modernleşmeye geçişe neden olmuştur. Gencer bu gelişmelerin miladını 1826 olarak vermektedir. Bütün bu gelişmeler, Tanzimat Fermanı (1839) ve Islahat Fermanı (1856) ile sonuçlanmıştır. ${ }^{10}$

Osmanlı dışındaki İslam dünyasında da durum pek farklı değildir. Batı'nın kazanmış olduğu zafer karşısında hayret ve dehşet ikileminde kalan Müslümanlar, Hindistan'da önce İngiliz işgaline karşı ayaklanmış, ancak ayaklanmanın çok kanlı bir şekilde bastırılması neticesinde dehşete kapılarak Seyyid Ahmed Han gibi Müslüman liderlerin görüşleri çerçevesinde İngiliz yönetimini tanımak zorunda kalmışlardır. Seyyid Ahmed Han, İngilizlerin 1857 ayaklanmasını 14 ay içerisinde çok kanlı bir şekilde bastırması sonrasında cihad ilan edilmesine karşı çıkmıştır. Müslümanlar için din ve cemaatin korunduğu bir alan oluşturulması gibi yeni bir strateji belirlemiştir. ${ }^{11}$ Batı dünyasının sahip olduğu teknik üstünlük, İslam dünyasında aynı zamanda bir hayret de oluşturmuş, yine Seyyid Ahmed Han önderliğinde Aligarh Müslüman üniversitesi, geleneksel eğitim kurumlarına alternatif olarak modern İslam anlayışını geliştirmek üzere İngiliz eğitim modeli uygun bir tedrisat temelinde kurulmuştur. ${ }^{12}$

Yaşanan süreçte İslam dünyası, Batı karşısında, tarihinde hiç karşılaşmad1ğ1 bir yenilgi almıştır. Batı dünyasının İslam dünyası karşısında kurmuş olduğu üstünlük, birçok Müslüman düşünür ve yazarı İslam dünyasının mevcut durumu karşısında düşünmeye itmiştir. Böylece İslam dünyasında Modernliğe yönelik çeşitli tepkiler ortaya çıkmıştır.

\section{II-) Modernliğe İlk Tepkiler}

İslam dünyasının modern Batı karşısında yaşadığı büyük yenilgi, ciddi sorgulamalara ve tedbir alma çabalarına neden olmuştur. "İnanıyorsanız en üstün sizsiniz" ayeti kapsamında yapılan sorgulamada Müslümanların üstün olmama durumunun ya inançtan kaynaklandığı veya dini yorumlama biçiminden kaynaklandığı sonucuna varan düşünürler, Batılıların iddia ettiği gibi geri kalmış-

9 Hilmi Ziya Ülken, Türkiye'de Çăgdaş Düşünce Tarihi, İstanbul, Ülken Yayınları, 1999 s. 36.

10 Bedri Gencer, Íslam 'da Modernleşme 18391939-, Ankara, Doğu-Bat1 Yayınları, 2012, s.63.

11 Selin Çağlayan, Müslüman Kardeşlerden Yeni Osmanlılar'a İslamcılık, İstanbul, İmge Yayınlar1, 2011, s. 37.

12 Mehmet Ali Büyükkara, a.g.e., s. 215. 
lığın nedeninin İslam dini olmadığını, asıl suçlunun Müslümanlar olduğunu ileri sürmüşlerdir. Ecdadımız, -çok kısa bir süre hariç- İslam'ı yanlış anladı ve yanlış yaşadı (veya hiç anlamadı ve hiç yaşamadı/onu anladığını ve yaşadığını zannetti) biz de onların çocukları olarak İslam'ı yanlış anladık ve yanlış yaşadık. ${ }^{13}$

Böylece, İ́slam'ın “özüne dönme” olarak ifade edilen bir “ihyacı” süreç başlamış oldu. "Gerçek İslam" ve "Tarihi İslam" ayrımı yapılmaya başlandı. Sonraki süreçte "İslamcılık" olarak ifade edeceğimiz bu tavrın temel karakteristikleri Akdoğan'a göre İslam'ın temel kaynaklarına dönüş, zamanın gereklerine göre dinin yeniden yorumlanması ve İslam'ın özüne uymayan kavram ve güçlerle mücadeledir. ${ }^{14}$ Bunu ise ancak içtihat kapılarını yeniden açarak yapmak mümkündür. Büyükkara ise daha ayrıntılı bir liste ile bu karakteristik özellikleri ortaya koymuştur. ${ }^{15}$ Buna göre ihyacı hareketlerin öne çıkan talepleri İslam'ın ilk kaynaklarına, yani Kuran ve sünnete dönüş, terakki için içtihat, Batı'dan faydalanma, tasavvufa çift taraflı bakış, eğitimde reform, İslam Birliği, şuraya dayalı yönetim ve yazılı üretimdir.

$\mathrm{Bu}$ yaklaşım, aynı zamanda Batılı oryantalistlerin dillendirmiş olduğu "İslam mani-i terakkidir" anlayışına da karşı çıkmış ve İslam toplumlarının geri kalmışlığının müsebbibi olarak İslam dininin kendisinin gösterilmesine karşı çıkmışlardır. Afganî'nin ve Namık Kemal'in de aralarında olduğu birçok kişi, başta Fransız oryantalist Ernest Renan olmak üzere pek çok oryantalistin dillendirdiği bu iddialara reddiyeler yazmıştır. Öyle ki bu reddiyeler ciddi bir külliyat oluşturmuştur. Cündioğlu'nun bu konudaki bir bibliyografya içerikli yazısı 94 sayfalık bir makaledir. ${ }^{16}$ Reddiye edebiyatının ortaya çıkışı Tanzimat döneminin sona erdiği zaman diliminde ve öncelikle Hindistan ve Mısır'da ortaya çıkıp, daha sonra Türkiye'ye sirayet ettiği görülmektedir. Temel tezi ise "vahşet ve bedeviyet içerisindeki bir kavmi dünyanın en yüce imparatorluklarından birisi haline yükselten İslam medeniyetidir." ${ }^{17}$

Batılıların bu iddialarına cevap verme arayışı ve İslam dünyasının yeniden eski ihtişamlı günlerine dönüş arayışı, bu dönemde genel olarak İslam dünyasında üç tür tavra neden olmuştur. Birincisi, Müslümanlığın geleneksel mirasına tutunmuş

13 İsmail Kara, "İslamcı Söylemin Kaynakları ve Gerçeklik Değeri”, Modern Türkiye’de Siyasi Düsünce 6: İslamcılık, ed. Y. Aktay, İstanbul, İletişim Yayınları, 2014, s. 36.

14 Yalçın Akdoğan, Siyasal İslam, İstanbul, İşaret Yayınları, 2000, 311.

15 Mehmet Ali Büyükkara, a.g.e., s. 23-26.

16 Dücane Cündioğlu, "Ernest Renan ve "Reddiyeler" Bağlamında İslam-Bilim Tartışmalarına Bibliyografik Bir Katk1", Divan, Cilt 1, Say1 2, 1996, s.1-94.

17 Mümtaz'er Türköne, Cemaleddin Afgani, Ankara, Türkiye Diyanet Vakfı Yayınları, 1994, s. 44. 
ve yenilenmeye karşı mesafeli bir tavır almıştır. İkincisi geleneksel mirası ciddi bir şekilde sorgulamış, hatta reddetmiş ve modern bir reformculuğa girişmiştir. Üçüncüsü ise bu iki tarz arasını bağdaştırıcı bir çizgi geliştirmiştir. ${ }^{18}$ Elbette bu hareketleri ve isimleri böylesi bir genel sınıflama içerisinde değerlendirmek bizleri birçok ayrıntıyı gözden kaçırma tehlikesi ile karşı karşıya bırakacaktır. Ancak bu kısım, çalışmanın boyutlarını aşacağı için kabaca değinilmesi ile yetinilecektir.

Bu dönemde benimsenen "ilk kaynaklara dönüş" yaklaşımı, sonraki süreçte daha belirgin bir şekilde ortaya çıkacak farklı tavırları da beraberinde getirmiştir. Normal şartlar altında "selefilik" olarak adlandırılan bu yaklaşım, kendi içerisinde hem muhafazakârlığı hem de modernistliği barındırmaktadır. Selefiliğin kelime anlamı "önce gelmek, geçmek, geçmişte kalmak" anlamlarına gelmektedir. ${ }^{19}$ Literatürdeki kavramsal anlamı ise Hz. Peygamber, sahabeler ve tabiin olmak üzere İslam'ın ilk üç asrını ifade eder. ${ }^{20}$ Genel olarak korumacı bir karaktere sahip olan selefiliğin tarihsel süreçte dört aşaması vardır. Birinci aşama icmal devrini ifade eder. Bu dönemde İslam, Arap yarımadası dışına yayılmış ve başka kültürlerle karşılamıştır. Bu karşılaşma sonucu bidatler ve yeni yorum biçimleri ortaya çıkmış ve İslam'ın bozulmasını önlemek için Ahmet ibn-i Hanbel ve İbn-i Hazm gibi isimler bu yeni durumları toptan reddederek Kuran ve Sünnetin lafz1na sarılmayı önermiştir. İkinci dönem Moğol istilası dönemidir. İslam dünyasının siyaseten zayıf olduğu bu dönemde de İbn-i Teymiyye ve İbn-i Kayyım El-Cezviyye selefiliği sistematik bir hale getirmiştir. Üçüncü dönem Muhammed bin Abdulvahhab ile başlayan dönemdir. Dördüncü ve son dönem ise modern dönemi ifade etmektedir. ${ }^{21}$

Selefiliğin tarihine kısaca bakıldığında görülen o dur ki, selefilik korumacı bir karaktere sahiptir. Ancak bu korumanın nasıl yapılacağı meselesi, modern dönem selefilerini keskin bir ayrım noktasına getirmiştir. Bir kısım selefiler korumanın ancak bütün yeni durumları reddedip, Kuran ve sünnete sarılmaktan geçtiğini düşünürken, diğer bir grup ise dinin, çağın gereklerine göre yeniden yorumlanıp, din haline gelmiş gelenekle hesaplaşarak mümkün olduğunu savunmaktadır. Akyiğitzade Musa "çağdaş uygarlığın temelleri Hz. Muhammed'in hadislerindedir. Kuran'dan ve Hz. Peygamber'in hadislerinden doğan İslam uygarlığı Avrupa'yı

18 Mehmet Ali Büyükkara, a.g.e., s. 20.

19 M. Sait Özervarlı, "Selefiyye”, Türkiye Diyanet Vakfi İslam Ansiklopedisi, (399-402), Cilt 36, İstanbul, Türkiye Diyanet Vakfı Yayınları, 2009, s. 399.

20 Ramazan El-Buti, Selefiyye, çev. V. Sönmez, İstanbul, Ehl-i Sünnet ve Cemaat Yayınları, 2009, s.7.

21 Birol Akgün ve Gökhan Bozbaş, “Arap Dünyasında Siyasi Selefizm”, Akademik Ortadoğu Dergisi, Cilt 7, Say1 14, 5-6. 
Ortaçağ barbarlığından kurtardı" demektedir ${ }^{22}$ Bu bağlamda muhafazakâr bir boyut öne çıkmaktadır. Ancak modernist selefiler ise İslam'ın bir akıl dini olduğunu, İslam'1 geri bırakan dini unsurların aslında geleneğin tortuları olduğunu, bu durumdan kurtuluşun ancak Ortaçağ' da kapatılan içtihat kapılarının açılması olduğunu ileri sürmektedirler. ${ }^{23} \mathrm{Bu}$ nokta ise selefiliğin modernist boyutunu gözler önüne sermektedir. Fakat her iki durumda da bir "aşağılık duygusu" üzerinden hareket edilmektedir. Muhafazakâr tavırda eldekini kaybetme korkusu ile çağa "sağır kalma" devam ettirilmek isteniyor; Modern tavırda ise modernliğin başarılarından gözleri kamaşan Müslümanların "batı gibi olma" kaygısı, modernliğin tüm varsayımlarını sorgulamaksızın onu kabule yöneltiyor, modernlik adına geleneği ise yerin dibine sokuyordu. Bu durum, Kara'nın ifadesi ile ele geçirilecek olan/umulan "namevcut"un elde olan mevcut ile takası gibi garip bir alışveriştir. ${ }^{24}$

Başlangıç itibariyle bu minval üzere gelişen Müslümanların modernlikle ilişkisi 20.yy.da oldukça farklı bir konuma ulaşmış ve birisi İslam adına modernliği ve modern dünyayı redde, diğeri ise modernliği olduğu gibi kabul edip İslam'1 ona uydurmaya yönelik bir çabaya dönüşmüştür.

\section{III-) Modernlik Karşısında İki Uç Tavır}

İslam dünyasının modernlikle ilişkisinde ortaya çıkan bu iki uç tavır, modernlikle sağlıklı bir ilişki kurulmasının önüne geçmiştir. Başlangıçta selefi bir tavır olarak tanımladığımız her iki yaklaşım da süreç içerisinde net bir ayrışmaya girişmiş ve bugün selefilik, modernist yaklaşımın zıddı olarak kullanılmaya başlanmıştır. Dolayısıyla 20.yy.ın özellikle ikinci yarısında gelişen selefilik, 19.yy.da ortaya çıkan selefilik ile oldukça farklı bir pozisyona evirilmiştir. Buna karşılık modernist akım da billurlaşmış ve ilk dönemde ortaya çıkan akımdan oldukça farklı bir pozisyon almıştır.

20.yy.da ortaya çıkan hali ile selefilik, birçok açıdan birbirinden farklı bir özellik göstermektedir. Ancak zihin yapısı itibariyle modern dünyaya karşı benzer bir nitelik arz etmektedir. Selefiliğin Suudi kolu, Hanbeli mezhebinin genel karakteristiği olarak zahire ve değişime yönelik tutumu nedeniyle modern dünyanın getirdiği yenilikler karşısında, klasik korumacı tavrını devam ettirmiştir. Örneğin yönetim meselesi özelinde ele alındığında, 19.yy.dan beri İslamcıların dile getirdiği tarihi ve sosyolojik bir çerçevede ortaya çıkan saltanat rejimini demokrasiye veya klasik İslamcıların ifadesiyle Meşruti Yönetime tercih etmişlerdir. Selefi

22 Mümtaz'er Türköne, a.g.e., s. 45.

23 Mehmet Ali Büyükkara, a.g.e., s. 24

24 İsmail Kara, a.g.e., s. 35. 
âlimlerden olan Suud'lu Abdulaziz b. Baas'a göre demokrasi, Allah'1n indirdiği ile hükmetmeyen bir rejimdir ve bu rejimde eğer İslamî yasaların hâkimiyetini sağlamaya dönük bir çalışma amacıyla, yani bir araç olarak kullanma niyeti yoksa o sistemde aday olmak ve oy kullanmak bile küfür ve şirktir. ${ }^{25}$ Yine Selefi alimlerden olan El-Makdisi'ye göre demokrasi bir din ve tağuti bir rejimdir. Ona göre "Bilinmelidir ki; tağut ismi kapsamına Allah-u Teâlâ ile birlikte kendisin de hüküm koyup, yasalar çıkarabileceğine yetkili zanneden herkes girmektedir." Benzer şekilde Es-Suri' de tanımında Tağut kelimesi üzerinden hareket etmektedir. “Allah'ın kitabı dışında kanun ve yasa koyan, hüküm çıkaran devlet liderleri, Allah'ın kitabına dayanmayan idari sistemler, Allah'ın kitabıyla hükmetmeyen mahkemeler, Allah'tan başka itaat edilen, hükmüne tabii olunan kullar"27. Yani demokrasi, Allah'ın yasama gücünün yerine insanın yasama gücünün oturtulması anlamında küfür ve şirk rejimi olarak nitelendirilmektedir.

$\mathrm{Bu}$ görüş ve düşünceleri daha ciddi bir çerçeve içerisine oturtan önemli bir başka isim ise Seyyid Kutup'tur. Selefi düşünce içerisinde kabul edilen İhvan hareketini radikalleştiren kişi olarak kabul edilen Kutup, Radikal İslamî hareketlerin en önemli ismi ve beslenme kaynağ İslam'1 keskin bir şekilde ayırmıştır. İçinde yaşanılan dönemi çağdaş Cahiliyye Dönemi olarak niteleyen Kutup, modern toplum düzenlerini de Cahiliyye Düzenler olarak adlandırmıştır. ${ }^{28}$ Kutup, Cahiliyye toplumunu, "İslam toplumu dışında kalan bütün toplumlar" biçiminde tanımlamaktadır. ${ }^{29}$ Kutup'a göre İslam, sadece düşünce ve inanç değil, aynı zamanda bir sosyal sistemdir. ${ }^{30}$ İslam'ın, toplumdan ve sosyal yaşamdan ayrı düşünülmesi doğru değildir. Sosyal, hukuki ve iktisadi düzenlerinde hâkim kılınmadığı sürece, o dine bağlı olanlar da Müslüman sayılmazlar. Toplumları da İslamî bir toplum olmaz. İslam'ın bu ilkeler ile birlikte hayata geçirilmedikleri sürece, ibadet ve bazı prensiplerin hayata geçirilmesi, o toplumu İslamî k1lmaz. ${ }^{31}$ Kutup, cahiliyye düzenlerinin ürettiği sorunlara İslamî çözümler üretme çabalarını da anlamsız çabalar olarak görür. Kutup’a göre kadın ve parlamento, kadın ve iş vs. gibi konularda İslam'ın ne dediğine ilişkin sorular

25 Abdulaziz b. Baas,," Demokrasi, Seçimler ve Bu Sistemlerde Çalışmanın Hükmü”, http://islamqa.info/tr/107166. Erişim Tarihi: 09.12.2014.

26 Muhammed El-Makdisi, Demokrasi Bir Dindir, terc. S. Y1lmaz, İstanbul, Şehadet Yayınları, 2010, s. 19.

27 Es-Suri, E. S., Demokrasi Dini, çev. M. Gezenler, Konya, Şehadet Yayınları, 2013, s.17.

28 Seyyid Kutup, Ístikbal İslam 'ındır, terc. H.F. Ulus, İstanbul, Hikmet Neşriyat, 2007, s. 12.

29 Seyyid Kutup, Yoldaki İşaretler, terc. A. Keskinsoy, İstanbul, Pınar Yayınları, 2011, s.116.

30 Beşir Musa Nafi, İslamcılık, terc. B. Aldiyai, İstanbul, Yarın Yayınları, 2012, s.102.

31 Seyyid Kutup, İslam 'da Sosyal Adalet, terc. H. Ünal, İstanbul, Hikmet Neşriyat, 2007, s.20. 
sormak doğru bir yaklaşım değildir. ${ }^{32}$ Fakat daha yanlış olan şey, İslam âlimlerinin bu sorulara cevap üretmeye çalışmalarıdır. Çünkü bu sorunların kaynağı, bir sistem olarak İslam'ın toplumdan kovulmasıdır. Dolayısıyla sorunların kaynağı olmayan İslam'ın bu sorunlara çözüm üretmesi mümkün değildir. Yeni Meselelere fetva vermeye çalışmak sadece komedyenlik yapmaktır. ${ }^{33} \mathrm{Bu}$ sebeple Kutup, modern dünya ile olan ilişkinin boyutunu farklı bir noktaya çekerek, İslam ile modern dünyanın iki karşıt kutup olduğunu ifade eder. ${ }^{34}$ Buna istinaden İslam adına modern dünyayı reddeder.

Selefi akımın zıddı bir pozisyonda olan modernist yaklaşım ise modern dünyanın gerçeklerine teslim olan bir tavrı ifade etmektedir. Aslında ifade ilk bakışta biraz sert kaçmış gibi görünebilir. Çünkü modernist yaklaşım çerçevesinde ele alınan isimler arasında oldukça farklı görüş ve yaklaşım sahibi isimler vardır. Nihai olarak da bu isimler aslında İslam dünyasının problemlerini çözme derdine sahip samimi isimlerdir. Ancak "teslim olmak" ile kast edilen modern düşünce yapısını olduğu gibi benimseyip, dini de bu perspektif üzerinden okumak çabası$\mathrm{n} 1$ işaret etmektedir.

Modernist düşünce geleneği içerisinde yer alan isimlerin arasında Seyyid Ahmed Han, Afgani, Abduh, Rıza, Fazlur Rahman, Suruş gibi isimler önde gelen isimler olarak sayılabilir. Modernist gelenek içerisindeki bu isimleri farklı veçhelere sahip olmasına rağmen, genel olarak ortak sayılabilecek özellikleri söz konusudur. Bu özellikler Büyükkara'ya göre geleneğe bakış, akıl merkezcilik, nazari yönü ve gevşek organizasyon yapısı, siyasetle ilişkileri, öncülerin profilleri gibi özelliklerdir ve bu konularda aşağı yukarı benzerlik taşır. ${ }^{35}$ Sıddıki de İslam modernizmin özellikleri arasında sebeplilik ve mucizeler, tasavvufa karşı tepki, taklide tepki ve akıl konularını saymıştır. ${ }^{36}$ Ayrıntılarına çok fazla girmeksizin ele alındığında, modernist düşünceyi metin merkezci ve tarihselci modernist düşünce olarak ikiye ayırmak mümkündür. ${ }^{37}$ Metinselci modernistler Kuran İslamcıllı̆̆1, Kuran'a dönüşcülük, Kuraniyye (Kuranizm) gibi adlarla anılmaktadırlar. Enam 38. ve 59. ayetlere dayanarak Kuran'nın apaçık olduğunu, başka bir dayanağa ihtiyaç duyulmadığını ifade etmektedirler. Kuran ayetlerinin metin manalarının

32 Seyyid Kutup, Íslamî Etüdler, terc. H.F. Ulus, İstanbul, Hikmet Neşriyat, 2014, 92.

33 Fehmi Cedan, Çăgdaş Arap Dünyasında İslamî Yönetim Tartışmaları, terc. M. Yolcu, İstanbul, Yöneliş Yayınları, 1989, s.61.

34 Ahmet Ayhan Koyuncu, İslamcılık ve Demokrasi, İstanbul, Pınar Yayınları, 2018, s.130.

35 Mehmet Ali Büyükkara, a.g.e., s. 209-211.

36 Mazharuddin Sıddıkî, İslam Dünyasında Modernist Düşünce, İstanbul, Dergah Yayınları, 1990, s.11-55.

37 Mehmet Ali Büyükkara, a.g.e., s. 214,222. 
evrensel olduğunu savunmaktadırlar. Sünnetle ilişki oldukça dar bir çerçevede şekillenmiştir. "Akla arz" veya "tabiata arz" denilen bir hadis kritik metodu ileri sürmüşler ve hadisleri bu çerçevede kritik etmişlerdir. ${ }^{38}$

Metin merkezli evrenselci modernistlerden farklı olarak tarihselci modernistler, hermönetik yaklaşım ile ilişkili düşünceler ortaya koydukları için hermönetik

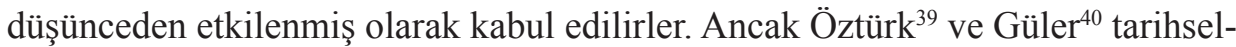
cilik düşüncesinin İslam ilim geleneği içerisinde olduğunu ileri sürerler. Her iki isim de öncelikle Hz. Ömer'i ve müellefe-i kulub'a dönük uygulamasını örnek gösterip, ayetlerin uygulamalarında tarihsel şartların belirleyici olduğunun İslam ilim geleneğinde olduğunu ileri sürerler. Hatta Güler, kitabını "tüm Ömeristlere" adamıştır. Öztürk Hz. Ömer örneği dışında başka birçok ismi ve rivayeti de aktararak tarihselciliğin İslam geleneğindeki köklerinin izini sürer. ${ }^{41}$

Tarihselciler evrensellik düşüncesine karşı çıkarlar ve Kuran'ın anlaşılmas1 için dönemin tarihsel şartlarının bilinmesi gerektiğini ileri sürerler. Tarihselci yaklaşıma göre ayetlerin indiği şartlar göz önüne alınmadığında, indiği dönemde gayet normal ve elverişli olan hükümlerin, çağdaş dünyanın şartlarına uymaması durumunda metinselci modernistler gayet mahcup bir tavırla, o ilahi hükmü çok da makul olmayan bir tarzda savunurlar veya o hükmü ve hükmün kaynağını tümüyle inkâr ederler. Örneğin kölelik, çok kadınla evlilik, kadının dövülmesi, cinsler arası eşitsiz miras dağılımı vs. konusunda tarihselciler hiçbir inkâr veya tevil yoluna gitmezler ${ }^{42}$ Bunun açık bir örneğini Öztürk ${ }^{43}$ ifade etmektedir. Öztürk'e göre örneğin çocuk yaşta evlilik İslam geleneğinde mevcuttur. Bu örnek sadece Hz. Aişe ile sınırlı değildir. Bunu inkâr etmek doğru değildir. Çünkü modern öncesi neredeyse tüm tefsirler bunu ifade eder. Yapılması gereken bu durumun tarihsel bir olgu olduğu ve dönemin şartları için normal olduğunu kabul etmektir. Yine tarihselci ekol içerisinde yer alan Güler, Kuran'ın yaşamın içinden doğmuş bir metin olduğunu, ancak yine yaşamın içerisinde anlaşılabileceğini, Allah gibi mutlak ve kutsal hale getirildiğini, ancak bunun yanlış olduğunu, doğru anlayışın hükümlerin vaz ediliş esprisini kavramak ve Allah gibi yeni hükümler

38 Mehmet Ali Büyükkara, a.g.e., s. 214.

39 Mustafa Öztürk, Kuran ve Tarihsellik Üzerine Yazılar: Çerçeve Yazılar, Örnek Konular, Ankara, Ankara Okulu Yayınları, 2018, s.58.

40 İlhami Güler, Sabit Din Dinamik Şeriat, Ankara, Ankara Okulu Yayınları, 2017, s.8

41 Mustafa Öztürk, a.g.e., s.50-58.

42 Mehmet Ali Büyükkara, a.g.e., s. 222-223.

43 Mustafa Öztürk, Kıvırmayın, Geleneğe Göre Kur'an'da Çocuk Yaşta Evlilik Bal Gibi De Geçiyor; Çözümü Tarihselcilik, https://www.youtube.com/watch?v=uY9yvLfQIFM adresinden 05.05.2017 tarihinde edinilmiştir. 
koymak olduğunu ifade etmektedir. ${ }^{44} \mathrm{Bu}$ görüşlerini ise insanın Allah'ın halifesi olmasına dayandırmaktadır. Bu durumu sadece Hz. Ömer'in kavradığını ve Nass'ın olduğu yerde bile şartlara göre içtihat yaptığını belirtmiştir. Kuran'ın lafzının mutlaklaştırılmasını "dondurulma" ve "mumyalanma" olarak gören Güler dinamik bir adalet idesinin peşinde olmayı maslahata daha uygun görmektedir. ${ }^{45}$ Yani ulema, Allah'ın halifesi ve peygamberin varisi olarak dini; tarihi ve toplumsal şartlar çerçevesinde, imani ve ahlaki ilkeleri hariç kalmak şartıyla, sosyal, siyasi ve hukuki konularda yenilemelidir.

Karaman'a göre modernist İslamc1lar din ve medeniyet olarak İslam〉dan vazgeçmiyorlar, ama bilerek veya bilmeyerek o sonuca gidiyorlar; çünkü İslam'1 doğru anlamanın anahtarı olan klasik usulü terk ediyorlar, Batı kaynaklı tefsir yöntemlerini kullanıyorlar, medeniyet, insan ve düzen olarak Batılı' dan farklı olmayan bir yapıyı İslam adına takdim ediyorlar. Bu ve benzeri görüşleri savunan modernistlerin birçok problem alanları vardır. En önemli problem alanlarından sayabileceğimiz iki husus, akıl ve bilim merkezci açıklama çalışmalarıdır. ${ }^{46}$ Islahatçı görüşün akıl-nakil dengesi gözetmesini de yeterli bulmayan modernistler çözümlemelerinde genellikle aklı öne almaktadırlar ve hayli rasyonel bir temele dayanmaktadır. Örneğin Abduh akıl ile nakil çatışması söz konusu olduğunda aklın tercih edileceğini belirtmektedir. ${ }^{47}$ Aydın'a göre İslam modernizminin temel tezlerinden birisi, Müslümanların sahip olduğu tarihi mirası ilmi ve rasyonel bir süzgeçten geçirmektir. ${ }^{48}$ Günümüz modernistlerinden Suruş ise "dini aydınlar"ın modern düşünceye sahip ve dini akıl ve mantıkla savunan kişiler olduğunu, onu böyle koruma yanlısı olduğunu ifade etmektedir. ${ }^{49}$

Modernistlerin ikinci handikabı ise bilim ile olan ilişkileridir. Modernistler, tıpkı batı dünyasındaki modern dönem düşünürleri gibi bilimi mutlaklaştıran bir düşünce yapısına sahiplerdir. Modern bilimin bulgularıyla Kuran'ın tefsir edilmesini savunmaktadırlar. Demir'e göre bu durumun iki önemli sebebi vardır. Birincisi Hristiyan Batı' da ortaçağ boyunca yaşanan din-bilim çatışması ve ikincisi

44 İlhami Güler, a.g.e., s.8.

45 İlhami Güler, Sünniliğin Eleştirisine Giriş, Ankara, Ankara Okulu Yayınları, 2017, s.78.

46 Hayrettin Karaman, "Modernistler Geçidi”, Yenişafak, http:/www.yenisafak.com/yazarlar/ hayrettinkaraman/modernistler-gecidi-2018664 adresinden 27.08.2015 tarihinde edinilmiştir.

47 Mazharuddin Siddiki, a.g.e., s.44.

48 Mehmet Aydın, "Fazlur Rahman ve İslam Modernizmi”, terc. M. Dă̆, M. Aydın, İslam içinde, Ankara, Ankara Okulu Yayınları, 2014, s.19.

49 Abdülkerim Suruş, “Özgürlük, Adalet ve Dindarlık”, Birikim Dergisi, S. 137, Eylül 2000, http://www.birikimdergisi.com/birikim-yazi/2515/ozgurluk-adalet-ve-dindarlik\#.VwtUC5yLQfI adresinden 28.08.2015 tarihinde edinilmiştir. 
Batı'nın ulaştığı teknolojik gelişmişlik düzeyidir. ${ }^{50}$ Ayrıca modern dönemdeki oryantalistlerin İslam dinini, Müslümanların geri kalmış olma sebebi olarak göstermeleri de bu anlayışta etkili olmuştur. Çünkü bu durum Müslümanlar açısından bir aşağılık psikolojisi yaratmıştır. ${ }^{51}$ Nihayetinde Bazı Müslüman düşünürler, Kuran'ın bilimle çelişmediğini ispatlamak için Kuran'ın modern bilimin bulguları çerçevesinde yorumlanmasını benimsemişlerdir. Örneğin bu anlayış çerçevesinde ilk kapsamlı tefsir denemesini ortaya koyan Tantavi Cevheri, El-Cevahir fi Tefsirül Kuran adlı eserinde Kuran ve bilimin çelişmediğini, Kuran'da 750 civarında ayetin müspet ilimlerle ilgili olduğunu, buna karşı sadece 150 civarında fikhi ayet olduğunu ifade etmiştir. ${ }^{52}$

Modernist düşüncenin yaklaşımları ele alındığında, rasyonalist bir açıklamanın çok da sağlıklı olmadığı, önce eleştirel teori daha sonra da özellikle postmodernist düşünürlerin aydınlanma ve akıl eleştirisi ile ortaya konmuştur. Frankfurt Okulu olarak da bilinen Eleştirel teori düşünürlerinden Horkheimer ve Adorno, akıl çağı olan aydınlanmanın başlangıçta dünyanın mistifiye edilmesine karşı bir tutum olduğunu, ancak daha sonra bir mite ve despotların iktidar aygıtına dönüştügünü ifade eder. ${ }^{53}$ Eleştirel teori sonrasında Postmodernizm ortaya çıkar ki Ketenci'ye göre bu aklın ölümüne tekabül eder. ${ }^{54}$ Postmodernizm, modernizmin aşırılıklarına bir tepki, akıl tanrısına, bilim peygamberlerine, rasyonellik ve bilimsellik kutsal kitabına, rasyonellik ve bilimsellik sancağı altında toplanmış düzenli, güvenli, disiplinli, tektipleşmiş ümmete ve cemaate, ilerleme ve gelişme cennetine isyandır. ${ }^{55}$ Aydınlanma düşüncesine dayalı modernlik kendisini bir meta anlatı olarak kurmuştur ama postmodernlik bu "meta anlatılara inanmazlık" olarak tanımlanmaktadır. ${ }^{56}$ Lyotard, bu bağlamda doğru-yanlış ayrımı yerine bü-

50 Şeyhmus Demir, “Kuran'ın Bilimsel Veriler Işı̆̆ında Yorumlanmasına Eleştirel Bir Yaklaşım”, ed. B. Gökkır, vd., Tarihten Günümüze Kuran'a Yaklaşımlar, Kuran ve Tefsir Araştırmaları-2 içinde, (s. 401424-), İstanbul, İlim Yayma Vakfi Yayınları, 2010, s.409.

51 İsmet Özel, Üç Mesele, İstanbul, Şule Yayınları, 2006, s. 59.

52 Şeyhmus Demir, a.g.e., s. 412.

53 Ahmet Çiğdem, Akıl ve Toplumun Özgürleşimi: Jurgen Habermas Üzerine Bir Çalışma, İstanbul, İletişim Yayınları, 2008, 28-29.

54 Taşkıner Ketenci, "Chaplin'in Gözlerindeki Şaşkınlık: Postmodern Akıl Eleştirisi Üzerine”, Flsf Felsefe ve Sosyal Bilimler Dergisi, Say1 4, 2007, s.61.

55 Abdullatif Tüzer, "Postmodernizm ve Tanrı'nın Ölümü: Öznenin Arkeolojisi Üzerine Bir Deneme", Milel ve Nihal, Cilt 12, Say1, 2, 2015, s.86.

56 Jean-François Lyotard, Postmodern Durum, çev. A. Çiğdem, Ankara, Vadi Yayınları, 2000, s. 12 . 
yük/küçük anlatı ölçütünü koyar. ${ }^{57}$ Böylece modernitenin rasyonalite merkezli hakikat iddiası bir anlatı/hikâye olarak görülür.

Ayrıca Suruş'un metninden hareket edildiğinde de aklı merkeze almanın önemli sakıncaları bulunmaktadır. Çünkü Suruş dini aydınların akıl ve mantık temelli düşünceye sahip olduğunu ifade etmesine karşın aynı konuşmasında "dinin aslında zihin ve aklımızı korumak için" geldiğini ifade etmektedir, ama aklın iç ve dış düşmanları olduğunu belirmektedir. "aklımızın içeride ve dışarıda birçok düşmanı var; çıkarlarımız, dış bağımlılıklarımız, bizim filan gruba, bu partiye, şu aileye, o sınıfa veya benzerlerine bağımlılı̆ımız, hatta propaganda bombardımanı altında olmamız, yaşadığımız asra ait olmamız... Bunların tümü bizi bağımlı kılmaktadır ve mantığımızın özgürce işlemesinin birer engel ve düşmanıdır. İç düşmanlarımıza gelince: bunlar bizim batıl bilgilerimiz, heveslerimiz ve arzularımız, kinlerimiz ve hırslarımızdır." ${ }^{88}$ Karaman'ın haklı eleştirisinde ifade ettiği gibi "bu kadar yanıltıcı ve saptırıcı amiller içinde işleyen aklı, sahih dinin hakemi, ölçütü ve onayı kılmayı" nasıl teklif edebiliriz? ${ }^{59}$ Dolayısıyla "aklın mutlaklaştırılması", kişileri yanıltıcı bir konuma sürükleyecektir.

Kuran'ın bilimsel veriler çerçevesinde yorumlanması da aynı hatayı verecek bir hareket noktasıdır. Çünkü bilimsel bir bilgi doğrulanabilir veya yanlışlanabilir olma özelliklerine sahiptir. Mantıkçı pozitivistlere göre bir bilimsel iddia doğrulanabilir olmalıdır. Doğruluk değerleri ise empirik belirlenim çerçevesinde olma1ıdır. ${ }^{60}$ Popper'a göre ise bilimsel bir yasa kesinlikle yanlışlanabilir bir konumda olmalıdır. ${ }^{61} \mathrm{Bu}$ iki ilke, modern bilim anlayışının benimsediği ilkelerdir. Ayrıca Kuhn, Bilimsel Devrimlerin Yapısı adlı eserinde, bir bilginin bilimsel olup olmadığı konusunda bilim topluluğunun keyfiliğine vurgu yapmıştır. Yani bir bilginin bilimsel olduğu veya olmadığı meselesi, bilim cemaatinin kabulüne dayalıdır, bu

57 Madan Sarup, Post-Yapısalcılık ve Postmodernizm, çev. Abdülbaki Güçlü, Ankara, Bilim ve Sanat Yayınları, 1997, s.210.

58 Abdülkerim Suruş, “Özgürlük, Adalet ve Dindarlık”, Birikim Dergisi, S. 137, Eylül 2000, http://www.birikimdergisi.com/birikim-yazi/2515/ozgurluk-adalet-ve-dindarlik\#.VwtUC5yLQfI adresinden 28.08.2015 tarihinde edinilmiştir.

59 Hayrettin Karaman, “Abdülkerim Süruş (2)”, Yenişafak, http://www.yenisafak.com/yazarlar/ hayrettinkaraman/abdulkerim-surus-2-2019918 adresinden 28.08.2015 tarihinde edinilmiştir

60 Gunnar Skirbekk, ve N. Gilje, Antik Yunan'dan Modern Döneme Felsefe Tarihi, terc. E. Akbaş, Ş. Mutlu, İstanbul, Üniversite Kitabevi, Tarihsiz, 540.

61 Bryan Magee, Karl Popper'in Bilim Felsefesi ve Siyaset Kuramı, terc. M. Tunçay, İstanbul, Remzi Yayınları, 1990, s.21. 
sebeple de bilimin kendisi bile metafizik temellere dayalıdır. ${ }^{62}$ Dolayısıyla her an doğrulabilir veya yanlışlanabilir olan bilimsel bir dayanak üzerinden ya da bir bilim cemaatinin kabulüne dayalı olarak, hakikat olduğunu iddia eden bir metni anlamaya çalışmak oldukça problemli sonuçlar doğuracaktır. Bugün mevcut olan bir bilimsel veri üzerinden açıkladığınız ayet, yarın o bilimsel verinin yanlışlanmasıyla veya Kuhncu anlamda paradigma değişimiyle birlikte batıl hükmünde olacaktır. Bu konuya güzel bir örnek Fransız Bucaille'in eserinde bulunmaktadır. Bucaille'e göre tatlı su ile tuzlu suyun birbirine karışmadığını anlatan Furkan Suresi 53. ayet, Fırat ile Dicle nehirlerinin ağzına işaret ettiği düşünülen bir olgudur. ${ }^{63}$ Buacaille, bu kitabı 1976 yılında yazmıştır. Fakat 1979 yılında Kaptan Custo'nun Akdeniz ile Atlas okyanusunun sularının birbirine karışmadığını keşfetmesiyle ayetin yorumu değişmiştir. Yarın başka bir gelişme olduğunda bu yorum yeniden değişecektir. Dolayısıyla bilimsel verilere dayalı tefsir, sürekli değişim yaşanan bilime dayanarak sağlıklı sonuç vermeyecektir.

Modernist ekolün en önemli isimlerinden birisi olan Fazlur Rahman'ın görüşlerine bakıldığında da birçok görüşünde modernliğe teslim olmuş bir etkinin olduğu görülmektedir. Örneğin Fazlur Rahman'a göre Kuran, Allah Resûlü'nün yaşadığı M. 7. asra yönelik ilahi bir müdahaledir ve mevcut hali ile günümüze uygulanamaz. ${ }^{64}$ Kuran'ın hükümlerinin, hukuki açıdan ifade edilirse o dönemin insanını ancak o kadar ileri götürebileceğini, daha ileri taşıyamayacağını, eğer Hz. Peygamber'in uygulanması imkânsız yüksek ahlaki formüller ortaya atmayı istemesi durumunda bunu rahatlıkla isteyebileceğini, ancak bu durumda bir toplum kuramayacağını ifade eden Rahman ${ }^{65}$, o dönemin insanını "geri ve ilkel" olarak görmekte ${ }^{66}$ ahlaki olarak düşük bir çerçevede değerlendirmekte ve aslında bu ifadeleri ile modernliğin kendinden menkul ilericiliğini onaylamış olmaktadir. ${ }^{67}$

Sonuç olarak, modernist anlayışın modern dünya ile kurduğu ilişki de problemli bir ilişkidir. Modern dünyanın kendinden menkul iddialarını mutlak doğru gibi görme tuzağına düşmüştür. Oysa her iki tavrın aşırılığına düşmeden, ama

62 Thomas S. Kuhn, Bilimsel Devrimlerin Yapısı, terc. N. Kuyaş, İstanbul, Kırmızı Yayınları, 2015, s.7374-.

63 Maurice Bucaille, Kitab-ı Mukaddes Kuran ve Bilim, çev. Suat Yıldırım, İzmir, Türkiye Öğretmenler Vakfı (TÖV) Yayınları, 1985, s.266.

64 Ömer Özsoy, Kur'an ve Tarihsellik Yazıları, Ankara, Kitabiyat Yayınları, 2004, s.81.

65 Fazlur Rahman, İslam, çev. M. Dağ, M. Aydın, Ankara, Ankara Okulu Yayınları, 2014, s.317.

66 Ebubekir Sifil, Fazlurrahman Kimdir, https://ebubekirsifil.com/fazlur-rahman-kimdir/ adresinden 22.02.2014 tarihinde edinilmiştir.

67 Ahmet Ayhan Koyuncu, a.g.e., s.151-152. 
tecrübelerinden de faydalanarak bir model geliştirme imkânı vardır. Bu model Hz. Peygamber'in yaşadığı dönemde kendi toplumu ile kurmuş olduğu düşünülen iliş̧ki biçimidir.

\section{IV-) Bir Model Önerisi}

Hz. Peygamber'in kendi toplumu ile kurduğu ilişkiyi okumak, bugün için Müslümanlara yaşadıkları dönemde toplumları ile kurmaları gereken ilişkiye dair bir model sunacaktır. Genel olarak bakıldığında Hz. Peygamber'in toplumu ile kurduğu ilişki üç boyutlu bir ilişkidir. Birinci boyutu devrimci boyuttur. Hz. Peygamber, devrimci boyutuyla yaşadığı toplumun zulme yol açan bazı uygulamalarını kökten kaldırmıştır. Ancak bu uygulama yerine yeni bir uygulama önerisi ile birlikte gelmiştir. Örneğin Putperest inanca meydan okunmuş ve yerine tek tanrı anlayışı konulmuştur. Başka bir örnek faiz uygulaması kaldırılmış ve yerine "karz-1 hasen" denilen faizsiz borç verme uygulamasını getirmiştir. Faizsiz borç vererek insanların dertlerini gidermenin faziletli bir davranış olduğunu ifade etmiş ve insanları birbirine borç vermeye teşvik etmiştir. "Sadaka veren erkeklere ve sadaka veren kadınlara ve Allah'a güzel bir ödünç verenlere, verdikleri kat kat artırır ve onlara şerefli bir mükâfat vardır" (el-Hadîd, 57/18). Bu ayetin dışında pek çok ayet ve hadis bu uygulamayı destekleyici bir konumdadır. Bir başka uygulama asabiyetle ilgili uygulamadır. Hz. Peygamber kavmiyetçiliği ve buna bağlı asabiyeti kaldırmış, yerine din kardeşliğini getirmiştir. Veda hutbesinde ifade edilen “Hiçbir Arap' ın Acem'e, hiçbir Acem'in Arap'a üstünlüğü yoktur. Üstünlük ancak takvadadır.” mealindeki hükmü, Arap dünyasında yaygın olan kavmiyetçilik anlayışının yasaklandığını belirtmektedir. Bu konuda örnekleri arttırmak mümkündür.

İkinci boyut muhafazakâr boyuttur. Hz. Peygamber sıfırdan yeni bir toplum kurmamıştır. Var olan toplumsal yapı içerisinde iyi olan uygulamalar da vardır. Hatta bu konuda Hz. Peygamber sahabelerinden birine hitaben "Ey Saib! Cahiliye çağında yaptığın faziletli şeylere İslam devrinde de devam et; misafiri ağırla, yetime ikram et ve komşuna iyi davran." ${ }^{\text {68 }}$ buyurmaktadır. Bunun dışında haram aylar uygulaması da devam ettirilen bir gelenek olmuştur. Yine erkeklerin sünnet edilmesi geleneği aynen devam ettirilmiştir. Ayrıca çok önemli toplumsal etkileri olmasa da şeytan taşlama, Kâbe perdedarlığı, savaşta sancak taşıma gibi Hz. Peygamber döneminde de devam eden çeşitli uygulamalar, Cahiliye dönemi olarak adlandırılan İslam öncesi dönemde uygulamaya konmuştur. ${ }^{69}$

68 Müsned, III, 425.

69 Hüseyin Alan, Hz. Peygamber Öncesi Mekke ve Arabistan, İstanbul, Beyan Yayınları, 2014, s.42-43. 
Üçüncü boyut ise 1slahçı boyuttur. Hz. Peygamber, dönemindeki uygulamaların bazılarını ıslah ederek devam ettirmiştir. Örnek olarak çok eşlilik, bu tür bir uygulamadır. Cahiliye döneminde 15-20'ye kadar çıkan çok evliliği, 4 kadınla sınırlamıştır. Köle ve cariye hakkındaki uygulama da bu çerçevededir. Kölelik kaldırılmamış ama ıslah edilmiş, kölelere haklar tanınmıştır. Hz. Peygamber bir hadisinde "Mülkiyeti altında bulunan (köle ve cariyelere) kötü muamele eden kimse cennete girmeyecektir. Onlara çocuklarınıza verdiğiniz değer gibi değer verin ve yediklerinizden yedirin... Onlar namaz kıldığı zaman artık o senin kardeşindir." buyurmuştur. ${ }^{70}$ Hem Kuran da hem de hadislerde kölelerin azad edilmesi teşvik edilmiş, birçok suçun telafisi için köle azad edilmesi şart koşulmuştur.

Hz. Peygamber bu uygulamaları gerçekleştirirken çeşitli yöntemler üzerinden hareket etmiştir. Bazılarını tek seferde kaldırırken bazıları da tedricen kaldırmıştır. Burada ciddi bir psikolojik ve sosyolojik süreç söz konusudur. Bu uygulamaların gerçekleştirilmesinde insanın özellikleri göz önünde bulundurularak yapamayacağı şeyler istenmemiştir. Bu durum olguları dikkate alan bir çözümlemedir. İdealler uğruna olgulara, yaşamın gerçeklerine savaş açılmamış, süreç içerisinde ideallerin hayata geçirilmesi hedeflenmiştir. Fransız Devrimi esnasında bir anda milyonlarca köle özgürlüğüne kavuşturulmuştur. Ancak bu pratik olarak karş1lık bulmamış, kölelik neredeyse 20.yy.ın başlarına kadar devam eden bir olgu olmuştur. Bunun dişında, teorik olarak eşitlik getirilmiş olmakla birlikte başka ayrımcılık türleri oluşturulmuştur. Örneğin Fransız Devrimi sonrası oy kullanma esası, vatandaşları aktif ve pasif olarak sınıflama çerçevesinde gerçekleştirilmiş, vergi vermeye gücü yeten vatandaşlar aktif, gücü yetmeyenler ise pasif olarak tanımlanmış ve pasif vatandaşların oy kullanmalarına izin verilmemiştir. ${ }^{71}$ Yine insan hakları konusunda ilk yazılı metni oluşturan ABD'de de durum 20.yy.1n ikinci yarısına kadar pek farklı değildir. Siyah-beyaz ayrımı çerçevesinde siyahlara, önceki dönemde kölelere layık görülen muameleden pek farklı bir uygulama ortaya konmamıştır. Bu durumlar göstermektedir ki toplumsal değişimlerin hızlı gerçekleşmesi, sorunun hızlı çözülmesine neden olmuyor. Bu gerekçeye dayanarak, Hz. Peygamber'in neden değişimleri tedrici bir çerçevede gerçekleştirdiği izah edilebilir.

Bu model aslında İslam'ın tarih tasavvuru ile de örtüşen bir modeldir. Çünkü İslam'ın tarih tasavvuruna göre insanlık Hz. Âdem ile başlar ve sonraki süreçte bozulmalar ve değişmeler yaşar. Bu bozulmaların ise ilahi müdahalelerle tekrar

70 Kütüb-i Sitte Terc. ve Şerhi, c. 17, s. 477, hadis no: 1111 -3691- (7098).

71 Mustafa Yıldız, Alternatif İnsan Hakları Kuramı, İstanbul, İşrak Yayınları, s.6566-. 
eski haline döndürülmesi ve değişmelere de uyumlu hale getirilmesi hedeflenir. Peygamberler ve kutsal kitaplar gönderilmesinin nedeni budur. Kuran'da Yahudilik ve Hristiyanlık reddedilmez, tahrif edildiği ifade edilir ve bu tahrifin düzeltilmesi hedeflenir. Hz. Âdem'den itibaren bütün peygamberlerin İslam'1 anlattığ belirtilir. Yine benzer bir tavır ahlakla ilgili bir hadiste yer almaktadır. Hz. Peygamber "Ben güzel ahlak1 tamamlamak üzere gönderildim." 72 buyurmaktadır. Yani sıfirdan bir ahlak kurmaz, var olan ama tahrif olmuş/edilmiş, eksik bırakılmış ahlakı tamamlamak üzere gelir. Bu anlamda Semavi dinler aynı çerçeve içerisindedir. Sıfirdan bir şey kurmaz, genel olarak bakıldığında bir dinin indirilişi yanlışı yok etmek, doğruyu tahkim etmek ve bozulanı tashih etmek amacına matuftur. İzzetbegoviç, Hristiyanlık veya sosyalizme bütünüyle yanlış demenin, İslam'a eksiklik atfetmek olacağını ifade etmektedir. Çünkü bu tür bir tavır, Hıristiyanlığın veya sosyalizmin İslam ile örtüşen doğrularını da inkâr etmektir. $^{73}$

Bu bağlamda bu model Müslümanlar için günümüzde uygulanabilir bir modeldir. Müslümanlar ne sosyolojik ve tarihsel gerçeklikleri göz ardı ederek modern dünyaya ve olgulara savaş açmalıdır ne de modernliğe bütünüyle teslim olmalıdır. Fransız sosyolog Durkheim, olgulara savaş açmanın anlamsızlığını şöyle anlatmaktadır: "Diyelim ki, bir sanayici olarak geçen yüzyılın yöntem ve metodlarıyla çalışmamı engelleyecek hiçbir şey yoktur, ama böyle yapacak olursam iflasa sürükleneceğim kesindir." "Y4 Yani günün şartlarını göz önünde bulundurmak mutlaka gereklidir. Aksi halde yıkım kaçınılmazdır. Burada modernliğe de belirli bir mesafe konulmalıdır. Modernliğin de değer yargıları olduğunu, bu yargıların mutlak hakikati temsil etmediği, dolayısıyla modern bir bakış açısı üzerinden İslam'1 okumanın doğru olmadığı aşikârdır. Ancak modernliğin kazanımları da göz ardı edilmemelidir. Modern dünyanın doğrularını sahiplenmek, yanlışlarını eleştirmek ama ona bir alternatif de önermek ve sslah edilebilir konumda olanları da ıslah etmek şeklinde bir hareket tarzı, Müslümanlar için hayati öneme sahip bir tarzdır. Fakat bu analizleri yaparken de dikkatli ve sağlıklı bir bakış açısı geliştirmek gerekmektedir. Örneğin modernliğin ürettiği birçok şey hayatımızın her alanına girmişken, demokrasi gibi bir yönetim modelini, sırf Batılıların onu bir sömürge aracı olarak kullanmasından dolayı İslam dışı görüp, kabul etmeme hatasına düşülmemelidir. Yani demokrasi bizatihi kötü bir olgu değildir. Elbette

72 Muvatta, Hüsnü'l-Hulk, 8; Ahmed b. Hanbel, 2/381.

73 Aliya İzzetbegoviç, Doğu ve Batı Arasında İslam, terc. S. Şaban, İstanbul, Nehir Yayınları, 1994, s.21-22.

74 Emile Durkheim, Sosyolojik Metodun Kuralları, terc. E. Aytekin, İstanbul, Sosyal Yayınları, 1994, s.37. 
en mükemmel rejim de değildir. F1khi bir kabul olarak eşya, doğası gereği iyi veya kötü değildir. Örneğin önemli İslam fakihlerinden Şatıbi “doğası gereği iyi (Mahza hayr) veya doğası gereği kötü (Mahza şer) olan hiçbir şey yoktur"75 demektedir. Eşyanın özünde mübahlık vardır. Ama bu eşya ile kuracağınız ilişki sizin niyetinizle alakalıdır. Örneğin bir silahı güvenliği sağlama amacı ile de kullanabilirsiniz, terör yaratma amacıyla da kullanabilirsiniz. Bu silahın doğasıyla ilişkili değil, sizin onu nasıl ve ne amaçla kullanacağınızla ilişkili bir durumdur. Fransız filozof Pascal da Düşünceler adlı eserinde "Kendi çıkarın için beni niye öldürmeye kalkıyorsun?” sorusuna “Sen ırmağın öbür yanında yaşayan biri değil misin? Dostum eğer sen de benim gibi bu tarafta oturuyor olsaydın, seni öldürmem cinayet sayılacak, ben de cani diye anılacaktım. Mademki sen öbür tarafta yaşıyorsun, seni öldürdüğüm için kahraman olacağım ve doğrusunu yaptığım söylenecek." ${ }^{\text {76 }}$ diyerek aynı eylemin farklı duruma göre farklı tanımlanabileceğini ifade etmektedir.

İslamî yaşamı ve modern yaşamı birbirine zıt ve hiçbir kesişim noktası bulunmayan iki ayrı evrensel küme olarak tahayyül etmek, yani modernliği bütünüyle gayrı İslamî olarak düşünmek, akıp giden yaşamı sskalamak demektir. Pratik olarak yaşanabilir bir örnek oluşturmak yerine ütopik ve gündelik yaşama aktarılması mümkün olmayan önerile sunmak, İslamî düşünceyi bir felsefe olmanın ötesine taşımayacaktır. Zaten İslam yaşanmak için inmiştir. Bu açıdan onu gündelik yaşamdan koparan ütopik öneriler ileri sürmek yaşanmak için inmiş bu dinin ruhuna aykırıdır. Bu sebeple yaşama aktarılabilir bir model, gündelik hayattan kopmamış veya onun faydalanabileceği alanlarından faydalanan, zararlı olarak gördüğü alanlarından uzaklaşıp, ona alternatif üreten ve ıslah edilebilir alanlarını da 1slah eden bir model olabilir.

Sonuç olarak modern dünya ile kurulan ilişki bu model çerçevesinde veya buna benzer daha gelişmiş bir model çerçevesinde kurulursa Müslüman toplumlar, hem kendi perspektiflerini kaybetmeyecek hem de modern dünyaya İslam adına karşı çıkmayacaklardır. Bu ise Müslüman toplumları daha sağlıklı bir konuma getirebilecektir. En azından modern dünyayı "tüm sorunların ana kaynağı" olarak görme ezberinden kurtaracak ve sorunlarını daha sağlıklı anlayıp, daha sağlıklı ve gerçekçi çözümler üretilmesine imkân sağlayacaktır.

75 İmam Şatıbî, El-Muvafakat: İslamî İlimler Metodolojisi, terc. M. Erdoğan, İstanbul, İz Yayınc1lik, 2010, 24-25.

76 Blaise Pascal, Düşünceler, çev. M. Karabaşoğlu, İstanbul, Kaknüs Yayınları, 1998, s.32. 


\section{Sonuç}

İslam dünyasının Modernlikle tanıştı̆̆ 19.yy.dan bu yana İslam ve modernlik ilişkisi tartışılmakta ve bu konuda çeşitli tavır alışlarla karşılaşılmaktadır. 19.yy. da modernlikle tanışmanın getirdiği İslam dünyasının en büyük krizi karşısında öncelikle İslam'1 savunma tepkisi ciddi bir temel oluşturma imkânından yoksun olduğu için reaktif bir çerçevede gerçekleşmiştir. Kaynaklara dönüş söylemi ve İslam'ın modernlikle uyumlu olduğu tezi bir arada savunulmuş ve bu dönemde selefilik olarak adlandırılan bir tepki ortaya çıkmıştır. Fakat süreç içerisinde selefi yaklaşım iki farklı ekole dönüşmüş, birinci kısım sadece kaynaklara dönmenin Müslümanları kurtaracağını ve Müslümanların tek çıkış yolunun bu olduğunu ileri sürerek modern dünya karşısında muhafazakâr bir tepki vermiştir. İkinci k1sım ise kaynaklara dönüş söylemini muhafaza etmesine rağmen kaynakların klasik yorumlarının günümüze cevap veremediğini, yeni bir tarzda yorumlanması gerektiğini ifade etmiştir.

Bu minval üzere gelişen İslam ve modernlik ilişkisinin günümüze yansımaları ya İslam'1 korumak adına modern dünyayı reddetmeyi veyahut da modern dünyanın getirilerini sorgulamaksızın onun perspektifinden İslam'1 yorumlamayı beraberinde getirmiştir. Bu yaklaşımların her ikisi de Müslümanların modern dünya ile sağlıklı bir ilişki kurmasını engellemektedir. Fazlur Rahman'ın klasik modernistler olarak nitelediği ilk dönem modernist düşünürlerin ortaya koydukları yaklaşımlar eleştirel bir gözle değerlendirildiğinde ve handikapları iyi tespit edilerek, özellikle de postmodern eleştirilerden faydalanarak modernlikle ilişki kurulmaya çalışıldığında yeni bir model oluşturabilmek mümkündür. Burada dikkat çekilmesi gereken nokta, bu yaklaşımın postmodern bir yaklaşım olması değil, postmodernliğin ciddi eleştirilerinden faydalanma noktasıdır.

$\mathrm{Bu}$ çerçeveden Hz. Peygamber'in kendi toplumunda ortaya koyduğu uygulamaları anlamaya çalışıp onları merkeze alan, modernlikle ve postmodernlikle mesafeli bir ilişki kuran, selefi ve tarihselci ekollerin eleştirilerinden faydalanan bir bakış açısı, Müslümanları içinde yaşadıkları dünya ile barışık ve Fazlur Rahman'ın ifade ettiği "resmi ikiyüzlü” tavırdan koruyacak bir modelin imkânını sunabilmektedir. Bu model, modern dünyanın "iyi" ve "kötü" taraflarını tespit etmeye çalışarak, duruma göre devrimci, muhafazakâr ve sslahçı bir tavır ile modern dünyanın gerçekleri ile yüzleşmeyi ve kendi değerlerini de buna kurban etmemeyi sağlayabilecek bir modeldir. 


\section{Kaynakça}

Akdoğan, Yalçın, Siyasal İslam, İstanbul, İşaret Yayınları, 2000.

Akgün, Birol - Bozbaş, Gökhan, “Arap Dünyasında Siyasi Selefizm”, Akademik Ortadoğu Dergisi, Cilt 7, Say1 14. 2012.

Alan, Hüseyin, Hz. Peygamber Öncesi Mekke ve Arabistan, İstanbul, Beyan Yayınlar1, 2014.

Aydın, Mehmet, "Fazlur Rahman ve İslam Modernizmi”, terc. M. Dağ, M. Aydın, İslam içinde, Ankara, Ankara Okulu Yayınları, 2014.

Baas, Abdülaziz, "Demokrasi, Seçimler ve Bu Sistemlerde Çalışmanın Hükmü”, http://islamqa.info/tr/107166. Erişim Tarihi: 09.12.2014.

Bauman, Zygmunt, Sosyolojik Düşünmek, terc. A. Yılmaz, İstanbul, Ayrıntı Yayınlar1, 2016.

Bucaille, Maurice, Kitab-ı Mukaddes Kuran ve Bilim, çev. Suat Yıldırım, İzmir, Türkiye Öğretmenler Vakfı (TÖV) Yayınları, 1985, s.266.

Büyükkara, Mehmet Ali, Çağdaş̧ İslami Akımlar, İstanbul, Klasik Yayınları, 2015.

Cedan, Fehmi, Çağdaş Arap Dünyasında İslamî Yönetim Tartışmaları, terc. M. Yolcu, İstanbul, Yöneliş Yayınları, 1989.

Cündioğlu, Dücane, “Ernest Renan ve "Reddiyeler” Bağlamında İslam-Bilim Tartışmalarına Bibliyografik Bir Katkı”, Divan, Cilt 1, Sayı 2, 1996.

Çağan, Kenan, “Modern Bir İdeoloji Olarak İslamcılığın İcadı”, İdeoloji, ed. K. Çağan, Ankara, Hece Yayınları, 2008.

Çağlayan, Selin, Müslüman Kardeşlerden Yeni Osmanlılar'a İslamcılık, İstanbul, İmge Yayınları, 2011.

Çiğdem, Ahmet, Akıl ve Toplumun Özgürleşimi: Jurgen Habermas Üzerine Bir Çalışma, İstanbul, İletişim Yayınları, 2008.

Demir, Şeyhmus, “Kuran'ın Bilimsel Veriler Işı̆̆ında Yorumlanmasına Eleştirel Bir Yaklaşım”, ed. B. Gökkır, vd, Tarihten Günümüze Kuran'a Yaklaşımlar, Kuran ve Tefsir Araştırmaları-2 içinde, İstanbul, İlim Yayma Vakfı Yayınları, 2010.

Durkheim, Emile, Sosyolojik Metodun Kuralları, terc. E. Aytekin, İstanbul, Sosyal Yayınları, 1994.

El-Buti, Ramazan, Selefiyye, çev. V. Sönmez, İstanbul, Ehl-i Sünnet ve Cemaat Yayınları, 2009. 
El-Makdisi, Muhammed, Demokrasi Bir Dindir, terc. S. Yılmaz, İstanbul, Şehadet Yayınları, 2010.

Es-Suri, E. S., Demokrasi Dini, çev. M. Gezenler, Konya, Şehadet Yayınları, 2013.

Gencer, Bedri, İslam 'da Modernleşme 1839-1939, Ankara, Doğu-Batı Yayınlar1, 2012.

Güler, İlhami, Sabit Din Dinamik Şeriat, Ankara, Ankara Okulu Yayınları, 2017. 2017. , Sünniliğin Eleştirisine Giriş, Ankara, Ankara Okulu Yayınları,

Hüseyin, Muhammed, Modernizmin İslam Dünyasına Girişsi, terc. S. Özel, İstanbul, İnsan Yayınları, 2004.

İzzetbegoviç, Aliya, Doğu ve Batı Arasında İslam, terc. S. Şaban, İstanbul, Nehir Yayınları, 1994.

Kara, İsmail, "İslamcı Söylemin Kaynakları ve Gerçeklik Değeri”, Modern Türkiye'de Siyasi Düşünce 6: Íslamcılık, ed. Y. Aktay, İstanbul, İletişim Yayınla$\mathrm{r} 1,2014$.

Karaman, Hayrettin, "Modernistler Geçidi”, Yenişafak, http://www.yenisafak.com/yazarlar/hayrettinkaraman/ modernistler-gecidi-2018664 adresinden 27.08.2015 tarihinde edinilmiştir.

, “Abdülkerim Süruş (2)", Yenişafak, http://www.yenisafak.com/ yazarlar/hayrettinkaraman/ abdulkerim-surus-2-2019918 adresinden 28.08.2015 tarihinde edinilmiştir

Ketenci, Taşkıner, "Chaplin'in Gözlerindeki Şaşkınlık: Postmodern Akı1 Eleştirisi Üzerine”, Flsf Felsefe ve Sosyal Bilimler Dergisi, Sayı 4, 2007.

Koyuncu, Ahmet Ayhan, İslamcılık ve Demokrasi, İstanbul, Pınar Yayınları, 2018.

Kuhn, Thomas S., Bilimsel Devrimlerin Yapısı, terc. N. Kuyaş, İstanbul, Kırmızı Yayınları, 2015.

Kutup, Seyyid, Ístikbal İslam'ındır, terc. H. F. Ulus, İstanbul, Hikmet Neşriyat, 2007. 2011. , Yoldaki İşaretler, terc. A. Keskinsoy, İstanbul, Pınar Yayınları, 
, Islam'da Sosyal Adalet, terc. H. Ünal, İstanbul, Hikmet Neşriyat, 2007. 2014.

, İslamî Etüdler, terc. H. F. Ulus, İstanbul, Hikmet Neşriyat,

Lyotard, Jean-François, Postmodern Durum, çev. A. Çiğdem, Ankara, Vadi Yayınlar1, 2000.

Magee, Bryan, Karl Popper'in Bilim Felsefesi ve Siyaset Kuramı, terc. M. Tunçay, İstanbul, Remzi Yayınları, 1990.

Mardin, Şerif, Yeni Osmanlı Düşüncesinin Doğuşu, İstanbul, İletişim Yayınlar1, 2002.

Nafi, Beşir Musa, İslamcılık, terc. B. Aldiyai, İstanbul, Yarın Yayınları, 2012.

Özel, İsmet, $\ddot{U}_{c ̧}$ Mesele, İstanbul, Şule Yayınları, 2006.

Özervarl1, M. Sait, "Selefiyye", Türkiye Diyanet Vakfi İslam Ansiklopedisi, Cilt 36, İstanbul, Türkiye Diyanet Vakfı Yayınları, 2009.

Özsoy, Ömer, Kur'an ve Tarihsellik Yazıları, Ankara, Kitabiyat Yayınları, 2004.

Öztürk, Mustafa, “Kıvırmayın, Geleneğe Göre Kur'an’da Çocuk Yaşta Evlilik Bal Gibi De Geçiyor; Çözümü Tarihselcilik”, https:/www.youtube.com/wat$\mathrm{ch} ? \mathrm{v}=\mathrm{uY} 9 \mathrm{yvLfQIFM}$ adresinden 05.05.2017 tarihinde edinilmiştir.

, Kuran ve Tarihsellik Üzerine Yazılar: Çerçeve Yazılar, Örnek Konular, Ankara, Ankara Okulu Yayınları, 2018.

Pascal, Blaise, Düşünceler, terc. M. Karabaşoğlu, İstanbul, Kaknüs Yayınları, 1998.

Rahman, Fazlur, İslam, çev. M. Dağ, M. Aydın, Ankara, Ankara Okulu Yayınlar1, 2014.

Sarup, Madan, Post-Yapısalcılık ve Postmodernizm, çev. Abdülbaki Güçlü, Ankara, Bilim ve Sanat Yayınları, 1997.

Sıddıkî, Mazharuddin, İslam Dünyasında Modernist Düşünce, İstanbul, Dergah Yayınları, 1990.

Sifil, Ebubekir, Fazlurrahman Kimdir, https://ebubekirsifil.com/fazlur-rahman-kimdir/ adresinden 22.02.2014 tarihinde edinilmiştir.

Skirbekk, Gunnar - Gilje N., Antik Yunan'dan Modern Döneme Felsefe Tari$h i$, terc. E. Akbaş, Ş. Mutlu, İstanbul, Üniversite Kitabevi, t.y. 
Şatıbî, E. İ. El-Muvafakat: İslamî İlimler Metodolojisi, terc. M. Erdoğan, İstanbul, İz Yayıncılık, 2010.

Şen, Adil, "Osmanlı'dan Günümüze Eğitimde Modernleşme Çabaları", EKEV Akademi Dergisi, Cilt 17, Say1 57, Ekim 2013.

Şentürk, Hulusi, Türkiye'de İslami Oluşumlar ve Siyaset: İslamcılık, İstanbul, Çıra Yayınları, 2011.

Suruş, Abdülkerim, "Özgürlük, Adalet ve Dindarlık", Birikim Dergisi, S. 137, Eylül 2000, http://www.birikimdergisi.com/birikim-yazi/2515/ozgurluk-adalet-ve-dindarlik\#.VwtUC5yLQfI adresinden 28.08.2015 tarihinde edinilmiştir.

Türköne, Mümtaz'er, Cemaleddin Afgani, Ankara, Türkiye Diyanet Vakfı Yayınlar1, 1994.

Tüzer, Abdullatif, "Postmodernizm ve Tanrı'nın Ölümü: Öznenin Arkeolojisi Üzerine Bir Deneme", Milel ve Nihal, Cilt 12, Say1, 2, 2015.

Ulu, Cafer, "1416 Sayılı "Ecnebi Memleketlere Gönderilecek Talebe Hakkında Kanun" ve Cumhuriyetin İlk Yıllarındaki Uygulamaları", Tarih Okulu Dergisi (TOD), Cilt 7, Sayı XVII, 2014.

Ülken, Hilmi Ziya, Türkiye'de Çağdaş Düşünce Tarihi, İstanbul, Ülken Yayınları, 1999.

Y1ldırım, Ergün, Bilginin Sosyolojisi, Bursa, Ekin Yayınları, 2007.

Yıldız, Mustafa, Alternatif İnsan Hakları Kuramı, İstanbul, İşrak Yayınları, 2010. 
